\title{
Description of palatal rugae size and direction in children with gender difference
}

\author{
Muhammad Arfianto Nur*, Nina Djustiana*, Yuti Malinda** \\ *Department of Dental Material Science and Technology Faculty of Dentistry Universitas \\ Padjadjaran, Indonesia \\ **Department of Oral Biology Faculty Of Dentistry Universitas Padjadjaran, Indonesia
}

\begin{abstract}
Introduction: Indonesia has a high number of children victims of disaster in the last five years, but the children do not have identity cards, causing difficulties in the identification process. Palatal rugae are considered unique in individuals, and their morphology remains stable throughout life. Data of palatal rugae pattern in children aimed to facilitate the process of identification of the child's gender. The purpose of this research was to discover the description of palatal rugae in children which can be used as a reference of gender identification in children. Methods: A descriptive research design was performed with purposive sampling method. Samples were taken from 119 maxilla images consisted of 69 images of girls maxilla and 50 images of boys maxilla. The study was performed by taking individual maxilla images with intraoral mirror and observing towards the direction of the palatal rugae according to the Carrea classification, and the size of palatal rugae according the Lysell classification. Results: The type IV direction and secondary size of palatal rugae were found to be dominant on both sides of maxilla in boys and girls. Conclusion: Palatal rugae in boys and girls were having the same direction which was the type IV, and the size of secondary rugae was found to be dominant on both sides of the palate. Palatal rugae also proofed to be able to become the complementary method for determining unidentified gender in children.
\end{abstract}

Keywords: Children, forensic odontology, gender, identification, palatal rugae

P-ISSN 1979-0201, e-ISSN 2549-6212 Available from:http://jurnal.unpad.ac.id/pjd/article/view/14323

DOI:http://dx.doi.org/10.24198/pjd.vol30no1.14323

Submission: Dec 2017 Publishing: Mar 2018

\section{INTRODUCTION}

Data released by the Indonesian Child Protection Commission states that in the last 5 years, the number of children affected by disasters on land, sea, and air reached 420 people. ${ }^{1}$ According to the
Department of Population and Civil Registry, the age requirement for registration of Identity Card/ Kartu Tanda Penduduk is at least 17 years old. ${ }^{2}$ then it can be concluded that the children still do not have ID cards and identify the children victims becomes more difficult because there is no identity

Corresponding author: Muhammad Arfianto Nur, Department of Dental Material Science and Technology Faculty of Dentistry Universitas Padjadjaran, Jl. Sekeloa Selatan I, Bandung, West Java, 40132, Indonesia. email: arfiantonur@gmail.com 
card found. Forensic odontology is very useful for identifying unknown victims especially in major disasters with mass casualties. Forensic odontology can assist investigators in identifying tooth through eeth, palatal rugae, lip scratches, and enamel ponents in the oral cavity such as lip print and palatal rugae in humans can make a real contribution in the identification process. ${ }^{3}$ Palatal rugae is considered to have an effect on fingerprinting and lip scanning, for the identification of individual medico-legitimate investigation Sassouni in 1957 said there's no similar and constan gat said there's no similar and constant palate uring growth. Its unguenss leads to research to identify individuals and gender. ${ }^{4}$ Palatal rugae has considerable resistance to changes in disease, trauma, and chemicals. Previous research has suggested that rugae palatina can survive from decomposition up to 7 days after death. ${ }^{5}$

The main problem of this research is how to describe the size and direction of palatal rugae in children based on gender differences. The purpose of this study is to determine the description of the size and direction of palatal rugae in children that can be used as a reference for gender identification in children.

\section{METHODS}

The descriptive research design was done by observing of the size and direction of palatal rugae in boys and girls under the age of 18 through intraoral images of the maxilla and evaluating the palatal rugae as to describe the size and direction of the palatal rugae in children based on gender differences. Before collect data, this study has obtained permission from the Health Research Ethics Committee Faculty of Medicine of Padjadjaran University number 1228/UN6.C1.3.2/ KEPK/PN/2016 year 2016

This study was conducted at Jatinangor Senior High School from November to December 2016 for the result of 119 maxilla images consisting of 69 images of girls maxilla and 50 images of boys maxilla. The classification of the palatal rugae size used in this study was according to the Lysell criteria, Lysell determined palatal rugae size into three groups, the first is Primary Palatal Rugae when the length of palatal rugae is $5 \mathrm{~mm}$ or more, the second is Secondary palatal rugae when the length of palatal rugae is $3-5 \mathrm{~mm}$, and the third is Fragmentary palatal rugae when the length of palatal rugae is $2-3 \mathrm{~mm}$, palatal rugae that has length less than $2 \mathrm{~mm}$ is ignored. The classification of palatal rugae direction used in this study was according to the Carrea criteria, Carrea classified palatal rugae into four types, type I is palatal rugae that directed postero-anterior, type II is palatal rugae that perpendicular with median line, type III is palatal rugae that directed anteroposterior, and type IV is palatal rugae that directed into many ways. The tools used in this research were Sony SLRAlpha 57, laptop with specifications Macro Sierra Processor Intel Core i5, and $\mathrm{O}_{7} \mathrm{DME}_{3}$ intraoral mirror. At the time of the data analysis process, the researchers rested for 10-20 minutes after analyzing 10 photos to avoid eye fatigue and decreased quality of the analysis.

\section{RESULTS}

Palatal rugae direction type I (postero-anterior) was seen as $2 \%$, the palatal rugae type (perpendicular to the median line) was see as $4 \%$, and $94 \%$ palatal rugae type IV (random direction) was found in boys maxilla, whereas type III (antero-posterior) was not found (Fig. 1). The type I (postero-anterior) palatal rugae was seen the median line) was seen as $9 \%$, and $85 \%$ palat rugae type IV (random direction) was found in girls maxilla, whereas type III (antero-posterior) was not found.

The primary type of the main palatal rugae size on the right side was $36 \%$ and on the left side was $40 \%$, the secon

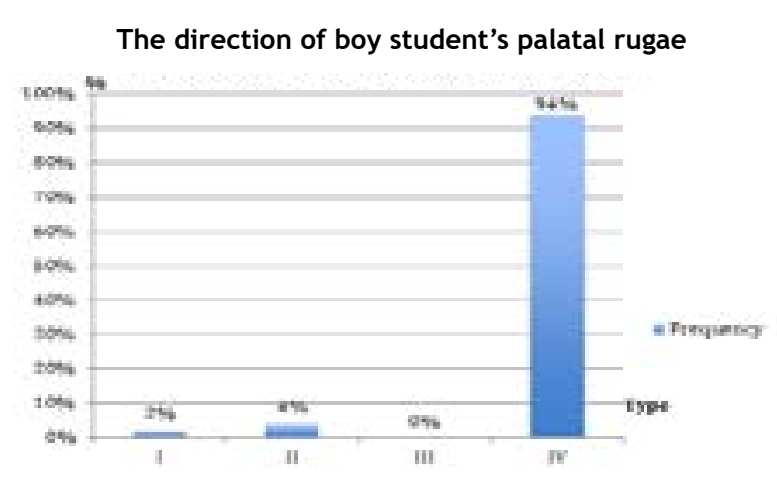

Figure 1. Frequency of palatal rugae direction on boy students at Jatinangor Senior High School
The direction of girl student's palatal rugae

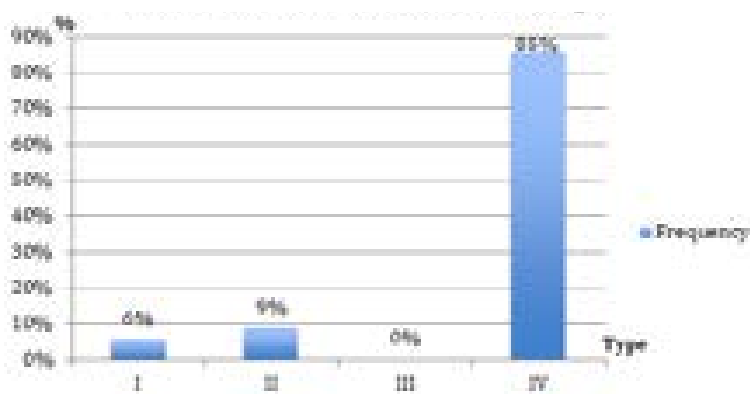

Figure 2. The Frequency of the direction girl student's palatal rugae at Jatinangor Senior High School

The size of boy student's palatal rugae

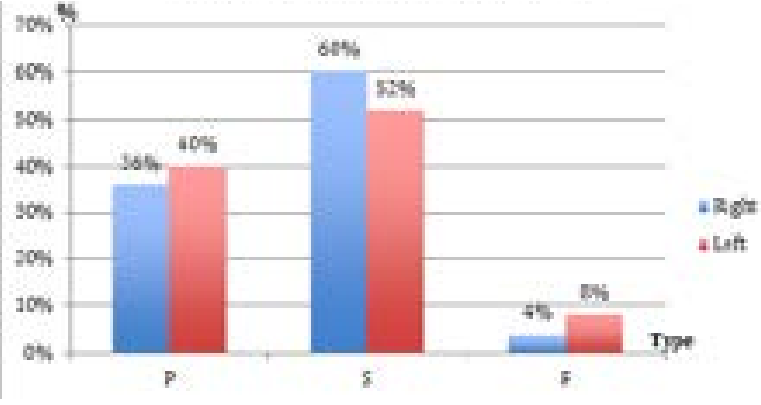

Figure 3. The Frequency of palatal rugae size on boy (Ptents at Jatinangor Senior High School (Primary (P) Secondary (S), Fragmentary (F))

The size of girl student's palatal rugae

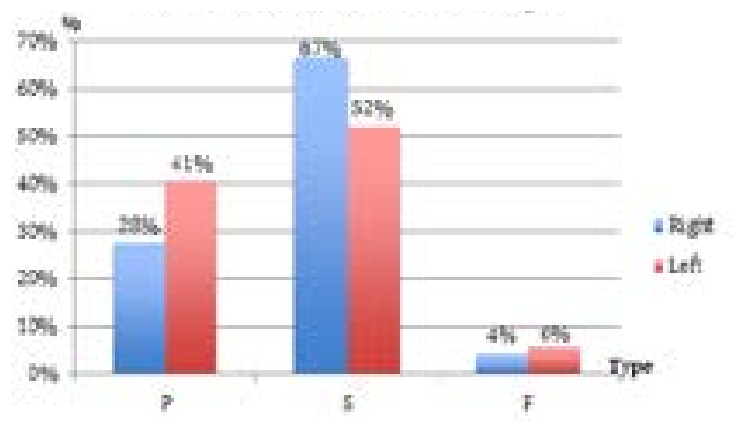

Figure 4 . The Frequency of palatal rugae size on girl students at Jatinangor Senior High School (Primary (P). Secondary (S), Fragmentary (F))

$60 \%$ and the left side was $52 \%$, the fragmentary type of the main palatal rugae size on the right side was $4 \%$ and the left side were $8 \%$ found in the boys maxilla. The results of this study show that the percentage of palatal rugae Primary and Fragmentary type are higher on the left side of boys maxilla, whereas the size of the Secondary type palatal rugae has a higher percentage on the right side of boys maxilla. The primary type of the main palatal rugae size on the right side was $28 \%$ and on the left side was $41 \%$, The secondary type of the main palatal rugae size of the maxilla on the right side was $67 \%$ and the left side was 5

$2 \%$, the fragmentary type of the main palatal rugae size on the right side was $4 \%$ and the left side was $6 \%$ found in the the girls maxilla. The results of this research show that the percentage of palatal rugae Primary and Fragmentary type are higher on the left side of girls maxilla, whereas the secondary type of the main palatal rugae size has a higher percentage on the right side of girls maxilla.

\section{DISCUSSION}

Identifying individuals with visual tests, fingerprints, and DNA is a method developed in the world of forensic identification, but the cost of DNA test isn't low and fingerprint is not always obtained, for example on burnt victim. ${ }^{6}$ This study indicates that the type IV palatal rugae direction is dominant in both male and female maxilla, with $94 \%$ percentage in boys and $85 \%$ in girls.

This study shows for the main palatal rugae, secondary type is more often seen in both maxilla of boys and girls, and more visible on the right side of maxilla than the left side. Kashima conducted research on Japanese ethnic children and Indian ethnic children, the result showed that Japanese ethnic children have more Primary rugae type than ethnic Indian children. ${ }^{7}$ Different results were also shown in a research of Indian Kerala populations, which is more palatal rugae in Primary type were shown. The research also showed the palatal rugae sizes of the Indian Manipuri population have more palatal rugae in Secondary type than the Primary type. Palatal rugae is unique in its shape, therefore, palatal rugae can be used as a complementary method for identifying individuals and determining gender. Palatal rugae cannot be the only reference for postmortem identification. Ahmed in 2015 conducted research on population of Sudanese Arabs, and the result was the mean number of primary and secondary rugae in males was greater than that of females, and then the primary rugae were predominant in both sexes compared to secondary and fragmented rugae. ${ }^{10}$ that result is different with this study, whic this study showed secondary palatal rugae is predominant in both sexes compared to primary 
and fragmentary. Different palatal rugaes form in two different populations may be due to genetic factors. ${ }^{9}$

Suggestions for dentists in further research are data of patient palatal rugae can be collected as an antemortem data to help identify if the data is needed, and then there should be further research on the relationship between palatal rugae, race/ ethnicity and gender differences.

\section{CONCLUSION}

Palatal rugae in boys and girls have the same direction which is a type IV and the size of secondary rugae is dominant on both sides of the palate, also palatal rugae can be a complementary method to determine unidentified gender in children.

\section{REFERENCES}

1. KPAI. Rincian data kasus berdasarkan klaster perlindungan anak, 2011-2016 [Internet]. 2016 [cited 2016 Oct 6]. Available from: http://bankdata.kpai.go.id/tabulasidata/data-kasus-pertahun/rincian-datakasus-berdasarkan-klaster-perlindungananak-2011-2016.

2. Disdukcapil. Persyaratan membuat KTP [Internet]. 2016 [cited 2016 Oct 6]. Available from: http://didukcapil.purworejokab.go.id/ prosedur-pembuatan-ktp-baru/.

3. Hermosilla Venegas $\mathrm{V}$, San Pedro Valenzuela J, Cantín López M, Claudio Suazo Galdames I. Palatal rugae: systematic analysis of its shape and dimensions for use in human identification. Rugas palatinas sist del análisis su forma y dimens para su uso en identificación humana
[Internet]. 2009;27(3):819-25. Available from: http://search.ebscohost.com/login.aspx?dire $c t=$ true $d \mathrm{db}=\mathrm{a} 9 \mathrm{~h} \& A \mathrm{~N}=56643252 \&$ lang=es\&site $=$ ehost-live

4. Thabitha R, Reddy R, Manjula M, Sreelakshmi $N$, Rajesh A, Kumar V. Evaluation of palatal rugae pattern in establishing identification and sex determination in Nalgonda children. J Forensic Dent Sci [Internet]. 2015;7(3):232. Available from: http://www.jfds.org/text. asp?2015/7/3/232/172447

5. Shanty C. Pemanfaatan ruga palatal untuk identifikasi forensik. Indones J Dent. 2008;15(4):261-9.

6. Dwivedi N, Nagarajappa AK. Morphological analysis of palatal rugae pattern in central Indian population. J Int Soc Prev Community Dent 2016;6(5):417-22.

7. Haffajee AD, Yaskell T, Sigmund S, Socransky SS. Palatine Rugae and Their Significance in Clinical Dentistry: A Review of the Literature. J Am Dent Assoc. 2011;139.

8. Savita JK, Yathindra Kumar BN, Satish G, Divya KT, Ranjitha J, Pujari RK. Prevalence of palatal rugae shapes in Karnataka and Kerala population: A cross-sectional study. $\mathrm{J}$ Int Soc Prev Community Dent [Internet]. 2016;6(3):230-3.

9. Shetty DK, Mali S, Divakar HD, Amit P, Dhairaysheel E, Harsh U. Palatal rugae patterns as a bioindicator for forensic identification in kodava and tibetan populations of india. J Int Oral Heal 2015;7(April):57-9.

10. Ahmed AA, Hamid A. Morphological study of palatal rugae in a sudanese population. Int $\mathrm{J}$ Dent. Hindawi Publishing Corporation; 2015;18. DOI: $10.1155 / 2015 / 650648$. 